\title{
A ÉTICA DIALÓGICA CULTURALISTA DO DIREITO
}

\section{ETHICS LAW DIALOGUE CULTURALIST}

\begin{abstract}
Afonso SoARES Oliveira SObRinho
Pós-Doutor em Direito pela Faculdade de Direito do Sul de Minas (FDSM). Doutor em Direito pela Faculdade Autônoma de Direito de São Paulo (FADISP). Advogado OAB/SP. Associado ao Conselho Nacional de Pesquisa e PósGraduação em Direito (CONPEDI) e a Sociedade Brasileira para o Progresso da Ciência (SBPC).
\end{abstract} affonsodir@gmail.com

\section{RESUMO}

O Direito não é produto de um pensamento unívoco; é construído a partir de relações éticas, jurídicopolíticas, culturais e institucionais estruturantesestruturadas na sociedade globalizada do século XXI. A formação da Ética Dialógica Culturalista do Direito visa à diversidade e ao pluralismo de instâncias e atores sociais por meio da democracia deliberativaparticipativa na criação, interpretação e aplicação do Direito, em especial no tocante à eficácia social dos direitos fundamentais. 0 processo dialético democrático participativo é fruto do amalgamento pelo choque entre infraestrutura e superestrutura sociais, e do salto qualitativo que permite avançar na compreensão culturalista constitucional, calcada na dignidade da pessoa humana, na boa-fé, no autorregramento da vontade, e na cooperação como instrumento democrático-deliberativo. Nesse diapasão, destacam-se a conciliação, a mediação, a arbitragem, as audiências públicas, os precedentes judiciais, o negócio processual, o orçamento participativo, a administração dialógica e outros mecanismos democráticos.

Palavras-chave: Constituição; Cultura; Democracia; Dialética; Direito.

\begin{abstract}
The law is not the product of a univocal thought, but constructed from ethical relations, legal and political, cultural and institutional structuring-structured in the global society of the twenty-first century. The formation of the culturalist dialogical ethics law aims to encompass the diversity and pluralism of bodies and social actors through deliberative, participatory democracy in the creation, interpretation and application of law. Especially regarding the effectiveness of fundamental rights. Here is the relevant work the prospect of a better society, with decent life for all. The participatory democratic dialectic process is the result of the amalgamation by the clash between social infrastructure and superstructure and qualitative leap up through the constitutional culturalist understanding, based on human dignity, in good faith, in selfie-regulation, in cooperation as a tool democratic decision-making. In this vein conciliation stand out, mediation, arbitration, public hearings, judicial precedents, procedural business, participatory budgeting, dialogical administration and among other democratic instruments.
\end{abstract}

Keywords: Constitution; Culture; Democracy; Dialectic; Law.

\section{SUMÁRIO}

INTRODUÇÃO; 1 A ÉTICA DIALÓGICA CULTURALISTA DO DIREITO; 1.1 A ética kantiana; 1.2 A ética em Paul Ricoeur: 0 justo; 2 ÉTICA, DIALOGICIDADE E ALTERIDADE EM INSTITUIÇÕES DEMOCRÁTICAS; 2.1 Ética e dialogicidade; 3 ACESSO À JUSTIÇA; CONCLUSÃO; REFERÊNCIAS. 


\section{INTRODUÇÃO}

O objetivo deste artigo foi trabalhar, a partir da análise documental, do método histórico e do procedimento dialético, o estudo da Ética Dialógica Culturalista do Direito para uma maior participação social e, por conseguinte, para permitir o acesso à justiça. Nesse sentido, faz-se mister o aprofundamento da análise dos instrumentos democráticos deliberativos participativos tanto judiciais como extrajudiciais, que passam pela solução de conflitos e contribuem para o fortalecimento da cidadania e do Direito a partir da legitimidade das decisões. A fonte principal do estudo são os valores e princípios expressos na Constituição Federal de base culturalista. ${ }^{1}$ Outra fonte é a dialética entre a realidade social e os direitos fundamentais como cultura jurídico-política emancipadora no acesso à justiça, a qual se utiliza das contradições sociais e das probabilidades possíveis quanto à concretude do Direito.

As relações entre Direito, Ética e Dialética são primordiais no entendimento da construção do Direito no século XXI. O estudo da Ética Dialógica Culturalista do Direito ${ }^{2}$ visa à formação de uma cultura democrático-participativa como força estruturante-estruturada em processo no século XXI com vistas ao acesso à justiça. Nesse sentido, a dialética é primordial na construção normativa, especialmente quando o intérprete se aproxima da realidade social no caso concreto. Faz-se necessário pensar em formas de democracia deliberativa a partir da pluralidade de atores e instâncias sociais nas soluções de conflitos, seja pela mediação, pela conciliação, pela arbitragem, por meio de audiências públicas ou por outras formas de

\footnotetext{
1 Acerca da concepção de constituição culturalista, J. H. Meirelles Teixeira e M. Garcia apresentam formidável entendimento: "Numa tentativa de fixarmos, num conceito culturalista de constituição, também os seus aspectos normativos e políticos, diríamos que as constituições positivas são um conjunto de normas fundamentais, condicionadas pela Cultura Total, e ao mesmo tempo condicionantes desta, emanadas da vontade existencial de unidade política, e reguladoras da existência, estrutura e fins do Estado e do modo de exercício e limites do poder político". (TEIXEIRA, J. H. M.; GARCIA, M. [Orgs.]. Curso de Direito Constitucional. Rio de Janeiro: Forense Universitária, 1991, p. 78).

${ }^{2}$ A norma jurídica se estrutura com base em valores e princípios e, num processo cíclico, sedimenta uma nova cultura em que a democracia-participativa (igualdade material) é primordial ao lado da autonomia como grau forte de legitimidade do direito construído no século XXI. Nesse sentido, o processo passa a ser regido pelo Direito público-privado (civil-constitucional) e se ramifica por todas as áreas do Direito. A ética com seus fundamentos filosóficos orienta esse percurso. Já a democracia permite uma interação entre instâncias e atores sociais pela comunicação, e quanto às escolhas possíveis e razoáveis à vida boa.
} 
efetivação do Direito. Quanto mais presente estiver a democracia deliberativa, mais o Direito se aproxima da norma efetiva ${ }^{3}$ e forma-se uma cultura sedimentadora da justiça distributiva.

A norma carrega consigo uma linguagem com padrões de comportamento social enquanto proposição prescritiva, comunicação institucionalizada e que impõe sanção (informação verbal). ${ }^{4}$ Porém, a norma por si só não garante a legitimidade social, nem a sua efetividade na relação entre autoridade e sujeito. Enquanto técnica, a norma, por meio de um discurso lógico que impõe autoridade através da sanção sem que se levem em conta os princípios norteadores do ordenamento jurídico, em especial o núcleo dignidade humana, parece desprovida de legitimidade. Manter a relação autoridade-sujeito é instrumento necessário para sua concretude, como ensina o professor Tércio Sampaio Ferraz Júnior (informação verbal). ${ }^{5}$

O debate sobre a força da norma no Direito e a linguagem de que ela se utiliza é enriquecedor quando se observa que a Constituição não se confunde com a lei. Ela se revela como dialogicidade conferida pela legitimidade da soberania popular ao constituinte, mas não termina nesse ponto. É força legítima para fechar o ciclo vital por sua efetividade e pela autoaplicabilidade dos direitos fundamentais pelo núcleo central dignidade da pessoa humana. Assim, irradia-se principiologicamente com seu manto sobre todo o sistema normativo. A capacidade deliberativa nessa perspectiva continua se irradiando até sua concretude plena, e retorna enriquecida como signos fortes de legitimidade, em uma dialética cíclica, aberta.

A ética dialógica trabalha com a organicidade do corpo social e, portanto, com a dialogicidade da alteridade como sistema aberto. Tudo passa pela democracia: a ideia de emancipação humana e a ética na pluralidade de instâncias e atores sociais. Quanto maior a diversidade, melhor será o funcionamento da democracia. Quanto maiores a inclusão e a participação, maior o grau de democratização de direitos.

\footnotetext{
${ }^{3}$ Trata-se de um processo dialético e cíclico que alimenta e retroalimenta o sistema jurídico a partir do qual se sedimenta uma cultura deliberativo-participativa dialógica. Os valores e princípios (superestrutura e a força normativa civil-constitucional) somam-se à participação dos diversos atores e instâncias sociais (infraestrutura social), resultando em uma norma efetiva pelo grau forte de legitimidade no processo de criação e interpretação. A ética dialógica culturalista pode ser comparada a um corpo. 0 cérebro é a ética, tendo como centro a autonomia e a liberdade; o coração, a democracia-participativa e representativa (a partir da concepção de igualdade material), que tem a dialogicidade das artérias como fios condutores do sangue representado pelos bens culturais - valores e princípios). A legitimidade (conferida no grau forte das decisões) são os impulsos nervosos. Os órgãos são as diferentes instâncias e os atores sociais atuando em conjunto. (OLIVEIRA SOBRINHO, A. S. de. A Pobreza na cidade de São Paulo como negação aos Direitos Humanos Fundamentais: a ética dialógica do Direito. 2015. Tese [Doutorado em Direito] - Faculdade Autônoma de Direito, São Paulo, 2015.)

${ }^{4}$ Aula de Comunicação Pragmática da Norma Jurídica ministrada em 09 de maio de 2012 na Faculdade Especializada em Direito (FADISP) por Tércio Sampaio Ferraz Júnior.

${ }^{5}$ Ibid.
} 
A ética é o "cérebro" como campo político-jurídico e a democracia, o "coração". As comunicações nervosas são a legitimidade. Os bens culturais são o próprio sangue que mantém vivo o corpo em sua organicidade. Os órgãos (atores e instituições) permitirão que o corpo se desenvolva, funcione, ande, movimente-se. A ética dialógica mantém vivo o Direito como força pulsante e real. 0 que mantém vivo o corpo social é a soberania popular. Mas um corpo social precisa ser entendido como um conjunto de indivíduos que pensam e agem calcados em princípios, valores e fundamentos, não em subjetivismos ou crenças pessoais.

\section{A ÉTICA DIALÓGICA CULTURALISTA DO DIREITO}

A Ética ${ }^{6}$ Dialógica Culturalista do Direito constitui-se de valores - “[...] qualidades puras, que atribuímos às coisas, às pessoas ou ao comportamento humano"7 - e princípios - “[...] mandamentos de otimização em face das possibilidades jurídicas e fáticas"8 - culturalmente expressos na estimativa afirmativo-emancipadora da vida boa, construídos ao longo da história da civilização: felicidade, justiça, lealdade, dignidade, liberdade, igualdade, solidariedade, além de outros expressos na realidade social do presente e princípios constitucionais. Seu núcleo é a dignidade da pessoa humana.

Como bens culturais são expressos em valores e princípios constitucionais irradiantes, entre os quais estão a igualdade, a liberdade e a solidariedade, assumem-se como núcleo estruturante-irradiante fomentador de valores e princípios normativos calcados na dignidade da pessoa humana, instrumentalizados pelos valores e princípios da soberania popular do cidadão. ${ }^{9}$

A ética se preocupa, podemos dizê-lo agora, com as formas humanas de resolver as contradições entre necessidade e possibilidade, entre tempo e eternidade, entre o individual e o social, entre o econômico e o moral, entre o corporal e o psíquico, entre o natural e o cultural e entre a inteligência e a vontade. Essas contradições não são todas do mesmo tipo, mas brotam do fato de que o homem é um ser sintético, ou dito mais exatamente, o homem não é o que apenas é,

\footnotetext{
${ }^{6}$ Fábio Konder Comparato considera os "[...] princípios éticos cardeais da verdade, da justiça e do amor [...] [que atuam] igualmente em todas as dimensões da dignidade da pessoa humana [...] desdobram-se [...] e especificam-se nos princípios de liberdade, igualdade e solidariedade" (COMPARATO, F. K. A afirmação histórica dos Direitos Humanos. 6. ed. São Paulo: Saraiva, 2008).

7 TEIXEIRA, J. H. M.; GARCIA, M. (Orgs.). Curso de Direito Constitucional. Rio de Janeiro: Forense Universitária, 1991, p. 60-64.

| ${ }^{8}$ ALEXY, Robert. Teoria dos Direitos Fundamentais. 2 ed. São Paulo: Malheiros, 2012, p. 116-153.

9 "[...] o conceito de cidadania desenvolve-se a partir do conceito rousseauniano de autodeterminação". (HABERMAS, J. Direito e democracia: entre facticidade e validade. Rio de Janeiro: Tempo Brasileiro, 2011. v. 2, p. 284).
} 
pois ele precisa tornar-se um homem, realizando em sua vida a síntese das contradições que o constituem inicialmente. ${ }^{10}$

A ética também é práxis expressa na igualdade, na liberdade e na solidariedade de oportunidades democrático-participativo-populares na horizontalidade cidadão-cidadão, cidadão-Estado e iniciativa privada-Estado. Nesse sentido, Castilho, em Refundação do Direito Econômico sob a égide dos direitos humanos: o capitalismo humanista, aborda a propriedade e a livre-iniciativa como vetores do capitalismo calcado na liberdade individual, rediscutindo-as e compatibilizando-as com outros valores (vida, dignidade, propriedade). ${ }^{11} 0$ indivíduo tem asseguradas sua privacidade, intimidade, honra e imagem, mas está inserido em uma comunidade. Por meio de uma interpretação sistemática, ${ }^{12}$ é possível ao exegeta aplicar a proporcionalidade necessária pela conjugação entre princípios, como do art. $1^{\circ}$, IV, com o art. 170, caput (ordem econômica e financeira) da Constituição Federal de $1988^{13}$, pela função social do Direito que permita a justiça social e, assim, uma existência compatível com a dignidade humana (valor-princípio do ordenamento jurídico), balizada na máxima kantiana do homem como um fim em si e nunca um meio para algo. ${ }^{14}$ Assim, a igualdade de todos perante a lei contempla uma vida com os recursos necessários à subsistência a todos ao lado da autonomia (capacidade de autodeterminação).

[...] ser humano digno é aquele que tem assegurada a possibilidade de determinar a si mesmo suas circunstâncias de vida presentes e seu destino, nas esferas privada (direito de escolher livremente os próprios projetos existenciais), pública (direito de participação no processo democrático) e mesmo social (ideia de mínimo existencial, de função social da propriedade e do contrato). ${ }^{15}$

\footnotetext{
${ }^{10}$ VALLS, Á. L. M. O que é ética. 9. ed. São Paulo: Brasiliense, 1994, p. 56.

${ }^{11}$ CASTILHO, R. dos S. Refundação do Direito Econômico sob a égide dos Direitos Humanos: o Capitalismo Humanista. In: CAMPELLO, L. G. B.; SANTIAGO, M. R. (Coords.). Capitalismo Humanista e Direitos Humanos: Estudos em homenagem aos Professores Ricardo Sayeg e Wagner Balera. Florianópolis: Conceito Editorial, 2013, p. 77.

${ }^{12}$ FREITAS, Juarez. A Interpretação Sistemática do Direito. 5. ed. São Paulo: Malheiros, 2010.

13 BRASIL. Constituição da República Federativa do Brasil de 1988. 9. ed. São Paulo: Revista dos Tribunais, 2004. $315 \mathrm{p}$.

${ }^{14}$ KANT, I. Fundamentação da metafísica dos costumes e outros escritos: texto integral. São Paulo: Martin Claret, 2008.

${ }^{15}$ CASTILHO, R. dos S. Refundação do Direito Econômico sob a égide dos Direitos Humanos: o Capitalismo Humanista. In: CAMPELLO, L. G. B.; SANTIAGO, M. R. (Coords.). Capitalismo Humanista e Direitos Humanos: Estudos em homenagem aos Professores Ricardo Sayeg e Wagner Balera. Florianópolis: Conceito Editorial, 2013, p. 77.
} 


\title{
1.1 A ética em Paul Ricoeur: 0 justo
}

A justiça entendida em sua complexidade na relação dialógica entre o sujeito e a alteridade em instituições justas e legítimas, portanto ético-jurídica-política, eis o grande desafio que Paul Ricoeur apresenta. ${ }^{16}$

Como ponto de partida cabe situar o pensamento Aristotélico da ideia de justiça com equidade. Nesse sentido, ao intérprete na busca da ratio legis exige-se um distanciamento necessário pelo juízo prudencial, deontológico e reflexivo exercido pelo terceiro representado pelo Estado enquanto instituição social. O justo numa perspectiva cíclica visa ao bem da vida que se traduz na felicidade do corpo social pelo pensamento plural do bem comum.

Por outro lado, uma concepção de justiça identificada na ética do humano pela revelação da vulnerabilidade existencial, que vai além da moral para o campo do viver bem em instituições legítimas tendo o "ser" como o centro das decisões, aproxima-se da visão Kantiana do homem como "um fim em si mesmo". Nesse sentido, para além da obrigação e da vinculação da norma, o sujeito responsável exerce papel social pela participação política na tomada de decisões (consciência, organização, reflexão e ação) na pólis com os instrumentos de democracia direta e indireta na formação cidadã com vistas à emancipação humana. A República diz respeito ao governo que inclua todos e vise o bem da coletividade para além de determinados grupos, clãs.

Como salienta o célebre Professor Tércio Sampaio Ferraz, ${ }^{17}$ na prática da retribuição da justiça, dois modelos implicam-se:

\begin{abstract}
Ora, o modelo vertical, a timoria (e a kolasis) parece prolongar um modelo préhumano que pressupõe hierarquia e retribui agressivamente uma ameaça agressiva. Ao contrário, o modelo horizontal, a poine parece pertencer exclusivamente ao gênero humano à medida que se liga à língua e a um mundo objetivamente construído. As grandes emoções vinculam-se ao modelo vertical (timoria), não porém, ao estabelecimento da poine que ocorre por meio de negociações (modelo horizontal). Neste último, uma vinculação da emoção à poine até parece rebaixar o homem, significando sua regressão ao animalesco. ${ }^{18}$
\end{abstract}

Os dilemas e conflitos permeiam histórias de vida, valores, crenças, o reconhecimento da responsabilidade, as sentenças, as penas, e muitas vezes as frustrações pelo não reconhecimento

${ }^{16}$ RICOEUR, P. O Justo 1: A justiça como regra moral e como instituição. 1. ed. Tradução Ivone C. Benedetti. São Paulo: WMF Martins Fontes, 2008.

${ }^{17}$ FERRAZ JR., T. S. Estudos de Filosofia do Direito: reflexões sobre o poder, a liberdade, a justiça e o direito. 2. ed. São Paulo: Atlas, 2003.

${ }^{18}$ Ibid., p. 217. 
da justiça, do perdão e da reabilitação, tanto pelo sujeito dito responsável, como pelo Estado, na impossibilidade de mensuração do bem que se perdeu. Essas relações sociais deveriam ser permeadas pela ética do humano (ética aristotélica da virtude como equidade e kantiana das obrigações vinculadas à garantia da dignidade humana).

Portanto, mais que viver em instituições formalmente isonômicas, faz-se primordial o retorno ao "mito" na compreensão filosófica do direito: a linguagem como espaço de comunicação do "eu" com o “outro" pelo respeito à pluralidade cultural e social e pela formação de um campo da legitimidade política como espaço de inclusão das diferenças visando ao bem comum. Nesse sentido, as variáveis cíclicas rompem com as tradicionais relações patrimonialistas egocêntricas calcadas na tradição, na família e na propriedade privada como centros de interesses, e passa-se das relações subjetivo-interpessoal-institucional do "ter" em direção às do "ser”.

Paul Ricoeur, em sua obra $O$ justo, ${ }^{19}$ traz dois eixos centrais voltados à ideia de justiça: como regra moral e como instituição; e como justo adjetivo usado na força do neutro grego: tò dikain (em Justiça e verdade e outros estudos).

Tendo como referência a "pequena ética" da obra Soi-même comme um autre (o simesmo como um outro), a ideia de justo perpassa pelo sujeito e sua relação com a pluralidade:

1) A prioridade da ética sobre a moral, isto é, a prioridade da visada da vida boa, com e para os outros, em instituições justas, sobre a norma moral;

2) A necessidade, no entanto, para a visada ética de passar pelo crivo da norma moral: essa passagem da ética à moral, com seus imperativos e suas interdições, é por assim dizer exigida pela própria ética, na medida em que o desejo da vida boa encontra a violência sob todas as suas formas; e

3) A legitimidade de um recurso da norma moral à visada ética, quando a norma conduz a conflitos para os quais não há outra saída a não ser a de uma sabedoria prática, à criação de decisões novas frente a casos difíceis: os hard cases do direito, da medicina ou da vida cotidiana.

[...] Nesta distinção entre visada da vida boa (visada ética) e obediência às normas (à norma moral), podemos facilmente reconhecer 'a distinção entre duas heranças': a herança aristotélica ['a ética é caracterizada pela sua perspectiva teleológica (de telos, que significa fim)']; e a herança kantiana ['a moral é definida pelo caráter de obrigação da norma e, portanto, por um ponto de vista deontológico (deontológico significando precisamente 'dever')]. ${ }^{20}$

19 RICOEUR, P. O Justo 1: A justiça como regra moral e como instituição. 1. ed. Tradução Ivone C. Benedetti. São Paulo: WMF Martins Fontes, 2008.

20 MAGALHÃES, T. C. de. A Reflexão de Ricoeur sobre o Justo. Síntese - Revista de Filosofia. FAFICH/UFMG. Belo Horizonte, v. 29, n. 93, p. 103-115, 2002. 
Em $O$ justo há a ideia de justiça como regra moral e a de justiça como instituição. Paul Ricoeur, em 0 Justo $1,{ }^{21}$ retoma seu pensamento de Soi-même comme um autre para situar a intersecção dos dois eixos ortogonais e dos seus percursos: o eixo 'horizontal' (constituição dialógica do si) - o si só constitui sua identidade numa estrutura relacional em que prevalece a dimensão dialógica sobre à monológica, pois o outro é o das relações interpessoais: a virtude da amizade é o tu, a virtude da justiça “é o a cada um, conforme indica o adágio latino: suum cuique tribuere, a cada um o que é seu", sendo portanto mediada pela instituição social; e o eixo 'vertical' - constituição hierárquica dos predicados qualificadores da ação humana em termos de moralidade. ${ }^{22}$

Nessa trajetória do justo há três níveis: o primeiro, constituído pelo predicado bom teleológico (busca do coroamento feliz, desejo da vida boa mediada pela instituição social justa); o segundo, deontológico (referência ao predicado obrigatório, nível da norma, do dever, da proibição, campo da violência institucional, voltando ao universal); e o terceiro, o plano da sabedoria prática, ${ }^{23}$ que é a estrutura do juízo moral em situação singular, numa situação de conflito e incerteza. Este nível propõe que o justo já não é o bom relativo ao outro (teleológico), nem o legal (deontológico), mas o equitativo, assumido pela ideia de justo, em especial nos casos difíceis.

As trocas, partilhas e retribuições geram prejuízo a outrem. Porém, é no "juízo reflexivo" que se pode libertar-se do desejo de vingança da justiça com as próprias mãos. Portanto, o ato de julgar envolve imparcialidade e independência do julgador sob a validade universal da lei. Porém, a reivindicação da universalidade remete, por um lado, à ideia de bem, e por outro, ao formalismo procedimental das operações da prática legal. ${ }^{24}$

No estudo do tema da justiça num diálogo com o pensamento de Paul Ricoeur (2008), direciona-se o presente artigo em três capítulos. O primeiro trata dos dilemas da justiça na

${ }^{21}$ RICOEUR, P. O Justo 1: A justiça como regra moral e como instituição. 1. ed. Tradução Ivone C. Benedetti. São Paulo: WMF Martins Fontes, 2008.

${ }_{22}$ Ibid., p. 7-9.

23 "[...] A sabedoria prática é um aprendizado adquirido das lembranças históricas e culturalmente em virtude do trágico e do sofrimento vivido e provocado. A sabedoria aparece quando já estamos cansados ou esgotados de tanto sofrer ou de fazer o outro sofrer; quando tomamos consciência de nossas ações injustas; então só nos resta procurarmos transcender essa fase optando de boa vontade por uma vida melhor. A 'sabedoria prática', portanto, é o recurso ético que permite à instituição conduzir as próprias ações de modo mais justo para tentar amenizar os conflitos interpessoais. [...] A sabedoria prática é um aprendizado que estabelece uma perspectiva ética para o sujeito da ação. Essa perspectiva consiste em uma aspiração ou desejo de querer para si, uma vida boa com e para os outros em instituições justas". (MUNOZ, F. A. G. A justiça e a sabedoria prática em Paul Ricoeur. 2011. Dissertação [Mestrado]. Universidade São Judas Tadeu. São Paulo: 2011).

${ }^{24}$ RICOEUR, P. O Justo 1: A justiça como regra moral e como instituição. 1. ed. Tradução Ivone C. Benedetti. São Paulo: WMF Martins Fontes, 2008, p. 9-13. 
contemporaneidade. 0 segundo trata da ideia do justo com equidade. 0 terceiro discute a dialogicidade como marco ético-jurídico-político balizador do ideal de justiça a partir da noção de democracia nas mutações existenciais que conduzam à dignidade humana pela emancipação. Por fim, conclui que a abordagem dos desafios apresentados por Paul Ricoeur à luz das mutações do presente com vistas à construção de um mundo plural e, portanto, “justo”, equânime.

A justiça está relacionada com a justa medida (equilíbrio e a proporção), enquanto concepção Aristotélica. A equidade se revela primordial no caso concreto. Porém, a linha tênue que separa o justo do injusto por uma decisão desproporcional pode se revelar em instrumento não da verdade que liberta, mas da falsidade e da mentira que condenam.

Aristóteles, em Ética a Nicômaco, no livro V, analisa a questão da justiça e da injustiça.

Com vistas à justiça e à injustiça, devemos indagar quais são as espécies de ações com as quais elas se relacionam, que espécie de meio termo é a justiça, e entre que extremos o ato justo é o meio termo [...] Ora: 'justiça' e 'injustiça' parecem termos ambíguos, mas como seus diferentes significados se aproximam uns dos outros a ambiguidade não é notada, enquanto no caso de coisas muito diferentes designadas por uma expressão comum, a ambiguidade é comparativamente óbvia [...] O termo 'injusto' se aplica tanto às pessoas que infringem a lei quanto às pessoas ambiciosas (no sentido de que quererem mais do que aquilo a que têm direito) e iníquas, de tal forma obviamente as pessoas cumpridoras da lei e as pessoas corretas serão justas. 0 justo, então, é aquilo que é conforme a lei e correto, o injusto é o ilegal e iníquo. ${ }^{25}$

Paul Ricoeur (2008), no estudo do justo, enfatiza a regra moral e a necessidade de instituições justas para além da complexidade do ato de julgar e seus reflexos no intuito da busca do bem e da vida boa, embora a violência estatal e as singularidades dos sujeitos nas relações interpessoais revelem muitas vezes o sofrimento humano, a dor para além da virtude da justiça, e digam respeito à interpretação da ação nas suas múltiplas relações interpessoais e cotidianas: reconhecimento, legitimidade dos sujeitos, procedimentos utilitaristas. Por sua vez, faz-se relevante um distanciamento necessário pelo juízo reflexivo no ato de julgar pela "sabedoria prática". Eis o grande desafio na compreensão do "si-mesmo como um outro", em Paul Ricoeur (2008), especialmente em se estabelecer uma relação de confiança e compromissos, assim como a de médico e paciente. Fazendo um paralelo com a busca da cura na relação médico-paciente, o ato de julgar pelo judiciário visaria a restabelecer a vida, não a morte; e a ética, não a vingança, impondo-se portanto um pacto de confiança entre o sujeito e a sociedade mediado pelo Estado.

${ }^{25}$ ARISTÓTELES. Ética a Nicômaco. 4. ed. Brasília: Universidade de Brasília, 2001, p. 91-92. 
A partir da comparação com o judiciário dos níveis do ato médico na relação de tratamento com o paciente podem ser identificados elementos centrais da nossa discussão.

0 primeiro pode ser chamado prudencial (constituindo o termo prudentia o equivalente latino do grego phronesis): a faculdade de julgar (para utilizar a terminologia kantiana) é aplicada em situações singulares nas quais um paciente individual é colocado numa relação interpessoal com um médico individual. Os juízos emitidos nesta ocasião exemplificam uma sabedoria prática de natureza mais ou menos intuitiva resultante do ensino e do exercício. 0 segundo nível merece ser chamado deontológico na medida em que os juízos revestem a função de normas que transcendem de diferentes formas a singularidade da relação entre um certo paciente e um certo médico, tal como aparecem nos 'códigos deontológicos de Medicina' que vigoram em numerosos países. Num terceiro nível, a bioética tem de se haver com juízos de tipo reflexivo aplicados à tentativa de legitimação de juízos prudenciais e deontológicos do primeiro e segundo níveis. ${ }^{26}$

Faz-se mister que o campo da filosofia do direito, como norte, aponte a direção do juízo reflexivo nas decisões, enquanto justo, pela relevância da percepção do dever-ser no caminho ao ser, enquanto elemento intuitivo no entendimento do próprio sujeito pelo olhar estético na determinação do valor humano como universalmente belo para além dos aparentes préjulgamentos.

Com vistas à ideia de justiça e injustiça, em Aristóteles, ${ }^{27}$ pode ser feita refleção acerca das diferentes acepções do justo enquanto uma relação de poderes. É nas relações de poder dos governos em relação aos outros membros e em relação à comunidade que se revelam os homens.

[...] 'na justiça se resume toda a excelência'. Com efeito, a justiça é a forma perfeita de excelência moral porque ela é a prática efetiva da excelência moral perfeita. Ela é perfeita porque as pessoas que possuem o sentimento de justiça podem praticá-la não somente em relação a si mesmas como também em relação ao próximo [...] praticamente a maioria dos atos prescritos pela lei é constituída de atos prescritos tendo em vista a excelência moral como um todo; de fato, a lei nos manda praticar todas as espécies de excelência moral e nos proíbe de praticar qualquer espécie de deficiência moral, e as prescrições para uma educação que prepara as pessoas para a vida comunitária são as regras produtivas da excelência moral como um todo [...]. [...] Se, então, o injusto é iníquo (ou seja, desigual), o justo é igual, como todos acham que ele é, mesmo sem uma argumentação mais desenvolvida. E já que o igual é o meio termo, o justo será um meio termo $\left[\ldots . .{ }^{28}\right.$

Portanto a ideia de justiça diz respeito, na concepção Aristotélica, aos atos que produzem a felicidade da comunidade política, a excelência moral, pela imposição da prática de

26 RICOEUR, P. Os três níveis do juízo médico. Colecção: Textos Clássicos Lusosofia. Covilhã: Universidade da Beira Interior, 2010 , p. 4.

${ }^{27}$ ARISTÓTELES, Ética a Nicômaco. 4. ed. Brasília: Universidade de Brasília, 2001, p. 93.

${ }^{28}$ Ibid., p. 93-95. 
certos atos e a proibição de outros. É o bem dos outros. É também a justiça uma virtude intrínseca ao ser humano, em busca do bem que lhe é próprio. Justiça, portanto, enquanto meio-termo, é proporcional. ${ }^{29}$

Quem condena ou absolve faz a (in)justiça dando ou retirando o que há de mais precioso na vida do homem: a sua liberdade. Em geral, assim, não só sujeita o indivíduo à decisão, mas subjuga a própria pessoa, em geral a mais fraca, e as relações subjetivo-interpessoalinstitucionais ficam ainda mais assimétricas. É preciso, mais que julgar, dialogar, e buscar uma solução de mérito legítima em que cada um participe para o menor sofrimento possível a todos.

\subsection{A ética kantiana}

Kant, na obra Fundamentação da Metafísica dos Costumes (2008), reconhece o homem como ser racional, autônomo e que cumpre um dever-moral como lei universal. Nesse sentido, o homem revela-se, pela razão prática, em ser dotado de dignidade, por ser um fim em si mesmo e não meio para outros fins.

Ora digo eu: - 0 homem, e, duma maneira geral, todo o ser racional, existe como fim em si mesmo, não só como meio para o uso arbitrário desta ou daquela vontade. Pelo contrário, em todas as suas acções, tanto nas que se dirigem a ele mesmo como nas que se dirigem a outros seres racionais, ele tem sempre de ser considerado simultaneamente como fim. ${ }^{30}$

Nesse diapasão, a ideia de racionalidade e dever moral impõe-se objetivamente como valor intrínseco ao indivíduo. A dignidade humana se revela como um dever moral (imperativo categórico) consigo e para com o outro como valor universal no tratamento de si e do outro como um fim em si mesmo. Tem como pressuposto a racionalidade existencial da boa vontade e da moral como valor supremo, e seu núcleo é a liberdade.

A vontade é concebida como a faculdade de se determinar a si mesmo a agir em conformidade com a representação de certas leis. E uma tal faculdade só se pode encontrar em seres racionais. Ora aquilo que serve à vontade de princípio objectivo da sua autodeterminação é o fim (Zweck), e este, se é dado pela só razão, tem de ser válido igualmente para todos os seres racionais. ${ }^{31}$

${ }^{29}$ Ibid., p. 93-95.

30 KANT, I. Fundamentação da metafísica dos costumes e outros escritos: texto integral. São Paulo: Martin Claret, 2008, p. 68, grifo do autor.

31 KANT, I. Fundamentação da metafísica dos costumes e outros escritos: texto integral. São Paulo: Martin Claret, 2008, p. 67, grifo do autor. 
O homem, como ser dotado de razão, deveria agir com boa vontade, prudência, virtude, com vistas à felicidade, não podendo fazer de si ou de seu semelhante um meio para vantagens.

A dignidade da pessoa humana como princípio constitucional norteador da ordem jurídica impõe-se diante de um capitalismo globalizado perverso ${ }^{32}$, especialmente quando observada a servidão moderna nas relações humanas, traduzida na exploração como regra para fins ilícitos, na corrupção, no descaso com a coisa pública e na banalização da vida humana, tendo como centro o consumismo desenfreado e fomentador de um meio ambiente em desequilíbrio que atenta contra à sadia qualidade de vida do presente e futuro geracional (conforme previsão constitucional brasileira de 1988 no art.225). Desvirtua-se o "princípio da moralidade" do homem para consigo e para com o outro, que deveria pautar-se em ações práticas racionais calcadas numa vontade como lei universalmente válida para todos, e que tivesse a dignidade da pessoa humana como "imperativo prático" do homem como um fim em si mesmo.

\begin{abstract}
Se, pois, deve haver um princípio prático supremo e um imperativo categórico no que respeita à vontade humana, então tem de ser tal que, da representação daquilo que é necessariamente um fim para toda a gente, porque é fim em si mesmo, faça um princípio objectivo da vontade, que possa por conseguinte servir de lei prática universal. 0 fundamento deste princípio é: A natureza racional existe como fim em si. [...] Age de tal maneira que uses a humanidade, tanto na tua pessoa como na pessoa de qualquer outro, sempre e simultaneamente como fim e nunca simplesmente como meio. ${ }^{33}$
\end{abstract}

Nesse diapasão fazem-se primordiais a autonomia e a razão prática kantiana (agir com o outro a partir do imperativo categórico como máxima na vida social). Tem-se por fundamento civil-constitucional o valor liberdade, e a dignidade da pessoa humana como princípio estruturante do ordenamento jurídico com vistas à ética dialógica do Direito, mediante a eficácia social de Direitos e garantias fundamentais com vistas à inclusão e à emancipação.

\title{
2 ÉTICA, DIALOGICIDADE E ALTERIDADE EM INSTITUIÇÕES DEMOCRÁTICAS
}

A ideia de sujeito de direito capaz se expressa no plano moral, jurídico e político. Nessa perspectiva, a noção de identidade narrativa do sujeito capaz é associada ora à ideia ética de bem, ora à ideia de obrigação, a partir das ações julgadas como boas ou más, permitidas ou

${ }^{32}$ Milton Santos identifica a globalização perversa a partir do totalitarismo do consumo (SANTOS, Milton. Por uma outra globalização: do pensamento único à consciência universal. 19. ed. Rio de Janeiro: Record, 2010.).

${ }^{33}$ KANT, I. Fundamentação da metafísica dos costumes e outros escritos: texto integral. São Paulo: Martin Claret, 2008, p. 69, grifo do autor. 
proibidas, enquanto sujeito de imputação. Há também um nexo entre a autoestima e a avaliação ética das ações que visam à vida boa (concepção aristotélica), assim como há um nexo entre o autorrespeito e a avaliação moral das ações submetidas à prova da universalização das máximas da ação enquanto concepção kantiana. Portanto, autoestima e autorrespeito definem a dimensão ética e moral do si-mesmo, como dimensão do homem sujeito de imputação éticojurídico-política.

O princípio da observação aos pactos enquanto regra de reconhecimento engloba todos que vivam sob as mesmas leis. No entanto, é o âmbito político o meio para realização das potencialidades humanas. Assim, é possível identificar algumas características norteadoras do campo ético-político: democracia direta e representativa, liberalismo, e o papel da política como norteadora e civilizadora, por meio de instituições sociais como centro da ética pública, a partir de princípios da vida em sociedade, no entendimento das relações subjetivo-interpessoalinstitucionais que conduzam à emancipação humana.

A ideia de governo justo e legítimo diz respeito à própria noção de democracia em suas várias acepções enquanto exercício da política.

Aristóteles, em Política, é singelo nas suas reflexões:

[...] Um princípio fundamental de uma forma democrática de governo é a liberdade [...]. É um dos princípios da liberdade que todos possam revezar-se no governo e, de fato, a justiça democrática é a aplicação de uma igualdade numérica e não de uma igualdade proporcional, consequentemente a maioria deve ser soberana, e o que a maioria aprove deve ser o resultado justo e final. Afirma-se que todo cidadão deve ser tratado com igualdade, e portanto, na democracia os pobres possuem mais poder que os ricos, pois há mais pobres que ricos, e a vontade da maioria é soberana. [...] outra característica é que cada homem deve viver como quer; diz-se que esse é o privilégio do homem livre, uma vez que, por outro lado não viver como se quer é a marca da vida de um escravo [...] mas a democracia e o poder do povo em suas formas mais genuínas baseiamse no princípio reconhecido de justiça democrática, segundo o qual todos têm a mesma importância numérica; esse princípio igualitário implica que os pobres não tenham uma participação maior no governo do que os ricos, e não deveriam ser governantes exclusivos, mas sim que todas as classes deveriam governar igualmente, de acordo com os seus números. É dessa maneira que os homens acreditam que podem assegurar a igualdade e a liberdade em sua Cidade. ${ }^{34}$

A democracia representativa e participativa é baliza da Constituição Federal de 1988, como herança desde a Grécia Antiga, passando pelos modernos ideais franceses de igualdade, liberdade e fraternidade. A constituição prevê instituições sociais livres, justas e solidárias, com efetividade dos direitos humanos fundamentais: cidadania, dignidade humana, pluralismo

${ }^{34}$ ARISTÓTELES, Política. 6. ed. São Paulo: Martin Claret, 2011 , p. 217-219. 
político, desenvolvimento para todos com justiça social (sem: fome, miséria, preconceitos e discriminação), conforme apregoado nos artigos $1^{\circ}$ a $3^{\circ}$ da Magna Carta.

Sérgio Buarque de Holanda (2008), em Raízes do Brasil, enfatiza que no Brasil a democracia foi sempre um mal-entendido, importada e acomodada por uma aristocracia rural e semifeudal em benefício de seus próprios direitos ou privilégios. ${ }^{35}$

Entre os direitos políticos assegurados no art. 14, caput, e incisos I, III e III da Constituição Federal, como expressão da cidadania, destacam-se os instrumentos de democracia participativa: o plebiscito, o referendo e a iniciativa popular.

As instituições públicas dos poderes executivo, legislativo e judiciário devem, portanto, nortear-se, nos seus atos, entre outros princípios, por: legalidade, publicidade, impessoalidade e moralidade, como expresso na Constituição Federal brasileira de 1988 - na administração direta ou indireta. As diretrizes norteadoras da administração pública, assim, devem estar voltadas ao interesse público, conforme dispõe o art. 37, caput, do texto constitucional. Na prática, a gestão pública volta-se à legalidade, e a norma fica carente de legitimidade (entendida como processo contínuo, mutável, cíclico e dialético de criação normativa) e de eficácia social.

A dignidade humana como princípio está expressa como direito fundamental no art. $1^{\circ}$, inciso III, no art. 170, inciso III, e no art. 226 , § $7^{\circ}$ da Constituição Federal enquanto estrutura do Estado de Direito, como salienta Jacintho. ${ }^{36}$ Ela perpassa, no campo principiológico, pelas relações subjetivo-interpessoal-institucionais, abarcando liberdades civis, étnicas, culturais: diz respeito às dignidades.

Neste século XXI, partimos da consciência de que a supremacia da Constituição e a aplicabilidade direta de suas normas se fundam no princípio da democracia, que a tutela da autonomia da vontade não é suficiente para proteger a dignidade, especialmente em sociedade desiguais como as nossas, e que métodos aparentemente neutros e mecânicos como a subsunção servem a encobrir escolhas valorativas, inevitáveis a qualquer processo de interpretação. ${ }^{37}$

Numa perspectiva de Paul Ricoeur (2008), para além do "eu” e do “tu”, pautada na pluralidade de atores que compõe nossa história, cabe estudar as formas de democracia enquanto construções republicanas com instituições sociais justas e éticas na forma, não obstante a emblemática realidade de não efetividade para os excluídos.

Montesquieu é favorável à democracia representativa:

${ }^{35}$ HOLANDA, Sérgio Buarque de. Raízes do Brasil. São Paulo: Companhia da Letras, 2008, p. 160.

${ }^{36}$ JACINTHO, J. M. M. Dignidade Humana: Princípio Constitucional. Curitiba: Editora Juruá, 2006.

${ }^{37}$ MORAES, M. C. B. de. Perspectivas a partir do Direito Civil-Constitucional. In: TEPEDINO, G. (Org.). Direito civil contemporâneo: novos problemas à luz da legalidade constitucional. São Paulo: Editora Atlas, 2008, p. 39. 
Como, em um Estado livre, todo homem que supostamente tem uma alma livre deve ser governado por si mesmo, seria necessário que o povo em conjunto tivesse o poder legislativo. Mas, como isto é impossível nos grandes Estados e sujeito a muitos inconvenientes nos pequenos, é preciso que o povo faça através de seus representantes tudo o que não pode fazer por si mesmo. ${ }^{38}$

Rousseau, por sua vez, em O Contrato Social, no capítulo XV, livro III defende a democracia direta:

A soberania não pode ser representada, pela mesma razão que não pode ser alienada. Ela consiste essencialmente na vontade geral e a vontade não se representa. Ela é a mesma ou é outra; nisso não há meio termo. Os deputados do povo não são, pois, nem podem ser seus representantes. São quando muito seus comissários e nada podem concluir definitivamente. Toda lei que o povo, em pessoa, não ratificou é nula; não é sequer lei. ${ }^{39}$

Acerca da ideia de democracia representativa, destaca-se que o governo ideal é o representativo - ou, nas palavras de Stuart Mill, após longas considerações sobre os governos desde a Grécia:

[...] é evidente que o único governo capaz de satisfazer completamente todas as exigências do estado social é aquele em que o povo todo possa participar; onde qualquer participação, mesmo na função pública mais modesta, é útil; um governo no qual a participação deverá ser, em toda parte, tão grande quanto permita o grau geral de aprimoramento da comunidade; e no qual, nada menos possa ser desejado do que a admissão de todos a uma parte do poder soberano do estado. Porém, uma vez que é impossível, em uma comunidade maior do que uma única cidade, que todos participem pessoalmente de todos os negócios públicos, a não ser de muito poucos, conclui-se que o tipo ideal de governo perfeito deve ser o representativo. ${ }^{40}$

Para além da democracia representativa, não se pode ignorar que criar e manter instituições justas e que promovam políticas públicas efetivas visando à vida boa para todos é um dos dilemas do capitalismo contemporâneo. Assim, é possível conciliar liberalismo e socialismo, mas há dificuldade em conciliar democracia e liberalismo.

Para reforçar o nexo de compatibilidade (melhor: de complementaridade) entre socialismo e democracia, foram sustentadas duas teses: antes de tudo, o processo de democratização produziria inevitavelmente, ou pelo menos favoreceria, o advento de uma sociedade socialista, fundada na transformação do instituto da propriedade e na coletivização pelo menos dos principais meios de

${ }^{38}$ MONTESQUIEU. O Espírito das Leis. São Paulo: Martins Fontes, 1993, XI, p. 6.

39 ROUSSEAU,J. O Contrato Social. 2. ed. Col. Grandes Obras do Pensamento Universal -13. São Paulo: Escala, 2008., III, p. 15.

40 MILL, S. Considerações sobre o governo representativo. Coleção Grandes Obras do Pensamento Universal - 56. São Paulo: Editora Escala, 2006, p. 65. 
produção; em segundo lugar, apenas o advento da sociedade socialista reforçaria e alargaria a participação política e, portanto, tornaria possível a plena realização da democracia, entre cujas promessas - que a democracia liberal jamais seria capaz de cumprir - estava também a de uma distribuição igualitária (ou ao menos mais igualitária) do poder econômico e político. [...] fica claro que o contraste contínuo e jamais definitivamente resolvido (ao contrário, sempre destinado a se colocar em níveis mais altos) entre a exigência dos liberais de um Estado que governe o menos possível e a dos democratas de um Estado no qual o governo esteja o mais possível nas mãos dos cidadãos, reflete o contraste entre dois modos de entender a liberdade, costumeiramente chamados de liberdade negativa e de liberdade positiva, e em relação aos quais se dão, conforme as condições históricas, mas sobretudo conforme o posto que cada um ocupa na sociedade, juízos de valor opostos $[\ldots]^{41}$

Identifica-se, no campo político, jurídico e social, a ética como superação do "eu e do tu" para o mundo plural "nós", portanto, ética cuja existência seja digna para todos. Note-se que, quando se fala em pacto social, parte-se de um ponto em que já se naturalizaram desigualdades, sem que haja condições existenciais de dignidade a todos os seus participantes. Fala-se nesse mesmo pacto quando se negam aos ditos cidadãos os bens básicos da vida e estes têm que se endividar para custear seus instrumentos de trabalho necessários à sobrevivência; ou quando se os obriga a escolher entre sua saúde e vida e o pagamento de suas dívidas. Poderia haver ética nesse debate? Trata-se de moralismo burguês.

O novo individualismo, o enfraquecimento dos vínculos humanos e o definhamento da solidariedade estão gravados num dos lados da moeda cuja outra face mostra os contornos nebulosos da 'globalização negativa'. Em sua forma atual, puramente negativa, a globalização é um processo parasitário e predatório que se alimenta da energia sugada dos corpos dos Estados-nações e de seus sujeitos. $[\ldots]^{42}$

O liberalismo é a doutrina do chamado Estado Mínimo. E por neoliberalismo entende-se uma defesa intransigente da liberdade econômica, da qual a liberdade política é apenas um corolário, no sentido de que uma sociedade é tanto melhor quanto mais extensa é a esfera da liberdade e restritiva de poder, porém, pela participação de todos. ${ }^{43}$

Wolfgang Leo Maar, em $O$ que é política, discute o papel da política como missão civilizadora.

Quando se classifica algo de 'autoritário', isto quer dizer mais do que simplesmente the atribuir uma atividade política que se impõe pela força. Significa atribuir-lhe um valor, uma referência que possui um sentido além do político. Do mesmo modo, quando consideramos uma pessoa 'democrática',

${ }^{41}$ BOBBIO, N. Liberalismo e Democracia. 6. ed., São Paulo, Brasiliense, 1994, p. 81-97.

42 BAUMAN, Z. Tempos Líquidos. Rio de Janeiro: Jorge Zahar Editor, 2007, p. 30.

${ }^{43}$ BOBBIO, N. Liberalismo e Democracia. 6. ed., São Paulo, Brasiliense, 1994, p. 87-88. 
emitimos uma opinião sobre as suas qualidades que não se esgota unicamente na sua prática. Neste sentido, a democracia seria algo mais do que uma determinada forma de governo ou de atividade política. Seria um valor, uma referência cotidiana que diz respeito ao conjunto de uma experiência humana e social, objetiva, acumulada ao longo da história na cultura. ${ }^{44}$

A democracia moderna passa pelas diversas formas de entendimento do papel do Estado, compreendido como a sociedade civil organizada na sua pluralidade de atores sociais enquanto exercício de papel ético-político. Assim, o pensamento de Paul Ricoeur, ${ }^{45}$ na medida em que tangencia a relação do eu com o outro, trata da vida boa na pólis mediante instituições justas, equânimes, que promovam o bem de todos, pelo respeito às diversidades sociais, culturais (de sotaques) e de pensamentos, não se configurando esta pólis como um espaço em que alguns se acham privilegiados em detrimento da maioria.

Para discutir a autoridade é importante entender se há a legitimidade, já que a distinção entre autoridade enunciativa e autoridade institucional é apenas provisória e de ordem didática, uma vez que não se trata de um consenso social, mas de instituições que usam dos discursos e escritos produzidos, enunciados e publicados para o convencimento.

Uma autoridade legítima é essencial para evitar os totalitarismos do Estado, muitas vezes representado por juízes engessados a uma dogmática jurídica elitista.

Hannah Arendt, em Origens do Totalitarismo, traz-nos à luz algumas reflexões fundamentais sobre o tema:

[...] A política totalitária não substitui um conjunto de leis por outro, não estabelece o seu próprio consensus iuris, não cria, através de uma revolução, uma nova forma de legalidade. 0 seu desafio a todas as leis positivas, inclusive às que ela mesma formula, implica a crença de que pode dispensar qualquer consensus iuris, a ainda assim não resvalar para o estado tirânico da ilegalidade, da arbitrariedade e do medo. [...] Essa identificação do homem com a lei, que parece fazer desaparecer a discrepância entre legalidade e a justiça [...] nada tem em comum com o lúmen naturale ou com a voz da consciência, por meio dos quais a Natureza ou a Divindade, como fonte de autoridade para o ius naturale ou para os históricos mandamentos de Deus, supostamente revela a sua autoridade no próprio homem. ${ }^{46}$

É no espaço público que se permite a pluralidade das relações inter-humanas para além do eu e o tu, do ter em direção ao ser. Portanto, a justiça se realiza como instituição social aplicando as regras às interações humanas, por um sistema partilha de papéis sociais e tarefas, para além da simples distribuição de valores no plano econômico. Assim, se o indivíduo precede

${ }^{44}$ MAAR, W L. O que é política. Col. Primeiros Passos. 16. ed. São Paulo: Brasiliense, 1994. 1994, p. 90-91.

${ }^{45}$ RICOEUR, P. O Justo 1. A justiça como regra moral e como instituição. 1. ed. São Paulo: WMF Martins Fontes, 2008.

${ }^{46}$ ARENDT, Hannah. Origens do Totalitarismo. São Paulo: Companhia das Letras, 2011, p. 514-515. 
o Estado, os direitos vinculados às capacidades e potencialidades humanas, enquanto membros da comunidade política, estão sujeitos à mediação institucional de um terceiro que conduza à autonomia e à emancipação, e não à submissão repressiva.

A técnica disciplinar na modernidade se constitui na normalização do sujeito pela produção de uma individualidade marcante que condena o "criminoso". Aponta suas características peculiares, rotula, julga e pune severamente. 0 poder normalizador define 0 lugar do sujeito na sociedade por qualidades ou defeitos que marcam sua autonomia de parte orgânica do corpo social e pressupõe a vontade, o querer, o poder-saber, a consciência de si. A técnica-ciência é tida como o espírito da modernidade, na subjetividade e organicidade do tempo-espaço das disciplinas normalizadoras de produção e reprodução de poderes. A norma jurídica é uma das técnicas refinadas de definição das posições sociais, econômicas e políticas enquanto ferramenta nas mãos de quem sabe e pode fazer o direito que, por isso, serve a quem pode fazê-lo na hierarquia social. A vontade de verdade é libertação ou prisão, absolvição ou condenação na luta interna das partes que unem o corpo social. ${ }^{47}$

Chauí, em seu artigo Acerca da Moralidade Pública, destaca a Justiça Comutativa, Distributiva e Social a partir de Aristóteles. ${ }^{48} \mathrm{~A}$ justiça distributiva se refere aos bens partilháveis (é a economia), no sentido de dar a cada um o que lhe é devido, e sua função é dar desigualmente aos desiguais para torná-los iguais. A justiça comutativa se refere às penas e recompensas legais que reparam danos cometidos contra cidadãos (o tribunal); mas a justiça fundante se refere a um bem que não pode ser partilhado e distribuído, somente participado: o poder político.

A política tem como finalidade a vida justa e feliz, ou seja, a vida humana digna de seres livres, e assim é inseparável da ética. ${ }^{49}$ Portanto, a soberania popular, seja nas urnas ou nas ruas, deve ser exercida como prática cidadã. 0 direito à manifestação pacífica é um exemplo clássico da cultura que se estabelece pelo diálogo diretamente entre o povo e as instituições no século XXI como campo ético-político-jurídico.

\footnotetext{
${ }^{47}$ BERTEN, A. Modernidade e Desencantamento: Nietzsche, Weber e Foucault. São Paulo: Saraiva, 2011, p. $131-157$.

${ }^{48}$ CHAUÚ, Marilena. Acerca da moralidade pública. Folha de São Paulo, São Paulo, 24 maio 2001, Caderno Tendências/Debates.

${ }^{49}$ Idem, Convite à Filosofia. 13. ed. São Paulo: Ática, 2006 p. 359.
} 


\section{1 Ética e dialogicidade}

A Constituição (lei maior) assegura que a ordem econômica, o trabalho e a liberdade permitam o bem-estar individual e social (art. $3^{\circ}$, I, II, III, IV) mediante a solidariedade, a equidade e a justiça. ${ }^{50} \mathrm{Em}$ síntese, o poder econômico deve ser compatibilizado com o valorprincípio dignidade da pessoa humana.

Igualdade de tratamento, direito de livre desenvolvimento da personalidade e vedação a tratamentos degradantes compõem, em suma, a dignidade da pessoa humana e são os grandes marcos a serem observados pelo sistema econômico, é dizer: devem nortear a elaboração das políticas públicas, a regulação da ordem econômica e a atividade judicial na arte de dizer o direito. ${ }^{51}$

A expressão ética no campo da sociedade civil compreende as organizações sem fins lucrativos, sindicatos e associações de bairros, como forças que se institucionalizam transmitindo valores sociais e participam das transformações de seu bairro e de sua comunidade, alcançando o mundo jurídico (endo e extraprocessualmente) por: mediação, conciliação, arbitragem, cooperação, boa-fé processual, autorregramento da vontade, uso dos precedentes judiciais no processo, administração dialógica, referendo, plebiscito, iniciativa popular e demais formas de deliberações que envolvam a pluralidade de instâncias e atores sociais, e alcancem direitos e garantias fundamentais utilizando a interpretação e aplicação do Direito a partir de valores e princípios constitucionais, tendo como fundamento a dignidade da pessoa humana nas relações público-privadas. Diga-se civil-constitucionalmente estabelecidas irradiando-se pelo ordenamento jurídico. Nesse sentido, o Direito realiza um movimento que alcança a vida social pela eficácia normativa. Partindo dos valores e princípios constitucionais (e a dignidade da pessoa humana como centro do sistema), pelo diálogo, alcança a esfera processual. Mas também, por sua força normativa constitucional como campo diálogos, alcança os instrumentos político-jurídicos decorrentes da igualdade material, como a participação democrática, e também os jurídicos extraprocessuais, como os Direitos Fundamentais previstos na Constituição Federal, que podem interferir na condução do poder político e na realização dos direitos fundamentais nessa área pelo sufrágio universal, por voto direto, secreto e universal, por

50 BRASIL. Constituição da República Federativa do Brasil de 1988. 9. ed. São Paulo: Revista dos Tribunais, 2004, p. 315.

${ }^{51}$ CASTILHO, R do S. Refundação do Direito Econômico sob a égide dos Direitos Humanos: o Capitalismo Humanista. In: CAMPELLO, L. G. B.; SANTIAGO, M. R. (Coords.). Capitalismo Humanista e Direitos Humanos: Estudos em homenagem aos Professores Ricardo Sayeg e Wagner Balera. Florianópolis: Conceito Editorial, 2013, p. 78. 
plebiscito, por referendo, por audiências públicas, pela eficácia social e pela sedimentação de uma cultura dialógica social. Alcança ainda as esferas administrativa e processual, inclusive na cooperação, na boa-fé processual e na primazia da decisão de mérito. 0 protagonismo do negócio processual e do amicus curiae, bem como as audiências públicas, são exemplos da própria dinâmica que se exige de um processo democrático.

Por sua vez, os instrumentos de democracia semidireta (participativa e representativa) como meios de realização da vontade popular precisam ser exercitados nesse sentido, inclusive para o fortalecimento das instituições que exigem a transparência na gestão pública. A expressão máxima da ética na vida pública é a política. A política deliberativa de maior peso, portanto campo ético-político, advém do Estado Democrático de Direito.

Dialogicidade é deliberação, participação, por meio de relações jurídico-políticas pluralistas e institucionais. Norma é a expressão ético-dialógico-cultural com vistas à vida boa. Justiça é o meio termo, proporcional e equitativo, de inspiração aristotélica. ${ }^{52}$

Entende-se o intérprete normativo como realizador de ambas as formas de justiça mediante previsão à punição ou à reparação do dano, como no caso da justiça comutativa (igualdade entre particulares). Confere-se tratamento desigual aos desiguais (equidade) nos casos em que mesmo o Estado não cumpre seu dever constitucional de garantir acesso à vida digna; e cumpre-se um papel jurídico-político do bem comum mediante a vida boa, a felicidade individual ou a coletividade. Em todos os casos busca-se o meio-termo, a felicidade, não se deixando de ouvir a comunidade, observando-se os bens culturais envolvidos e valorando-se os princípios fundamentais da Constituição Federal (tendo como princípio-fonte a dignidade da pessoa humana). Contudo, é preciso uma dialogicidade como cultura inclusiva-deliberativaparticipativa que dê à estrutura normativa a legitimidade expressa na força normativa efetiva.

A dialogicidade entre sociedade civil e sociedade política expressa pelo Estado no Direito, nas leis, confere legitimidade normativa pela sua força de efetividade. Quanto maior a ação participativa e deliberativa da sociedade na esfera pública, ${ }^{53}$ maior a efetividade normativa.

No Estado liberal, a cultura é burguesa e a ética é individualista. A dialogicidade é vertical-representativa, expressa na vontade geral. Do conflito entre os Estados liberal e social

52 ARISTÓTELES. Ética a Nicômaco. 4. ed. Brasília: Universidade de Brasília, 2001.

53 "A esfera pública pode ser descrita como uma rede adequada para a comunicação de conteúdos, tomadas de posição e opiniões; nela os fluxos comunicacionais são filtrados e sintetizados, a ponto de se condensarem em opiniões públicas enfeixadas em temas específicos. Do mesmo modo que o mundo da vida tomado globalmente, a esfera pública se reproduz através do agir comunicativo, implicando apenas o domínio de uma linguagem natural [...]". HABERMAS, J. Direito e democracia: entre facticidade e validade. Rio de Janeiro: Tempo Brasileiro, 2011. v. 2, p. 93. 
advém a democracia deliberativo-participativa expressa na horizontalidade do Estado Democrático de Direito. Nele, todos são cidadãos (maioria e minorias) e as instituições se submetem à Constituição com vistas a sua efetivação.

Dos contrastes entre a cultura autoritária, individualista e as necessidades do povo há um ponto de intersecção entre verticalidade (representação) e horizontalidade (participação). Desse choque surge um princípio que passa a nortear a vida em sociedade: a dignidade da pessoa humana. Em seu trajeto ético-dialógico, ela opera com os instrumentos deliberativoparticipativos (jurídico-político, pluralista e institucional, portanto cultura estruturanteestruturada legitimada) expressos na soberania popular, no meio-termo e no movimento cíclico, e se completa como princípio culturalmente estruturado e força normativa.

A cultura estruturante-estruturada tem por base os axiomas (liberdade, igualdade e solidariedade) a partir da legitimidade dos poderes estabelecidos na pluralidade de atores e instâncias sociais como democracia deliberativa, e seu núcleo é a dignidade da pessoa humana. Por sua vez, a cultura estruturada-efetivada se desenvolve como tipo-ideal (grau forte presentificado) de práxis principiológica normativamente legitimada a partir da simetria entre a eficácia social da norma e a realidade social, e tem na política deliberativa sua razão de ser, retroalimentando o sistema como cultura.

As estruturas jurídicas, uma vez objetivadas, o que equivale a dizer positivadas, não são esquemas inertes, mas realidades que além de se inserirem no todo do ordenamento, mutuando significações, recebem novos impactos de novos fatos e valores emergente. A dialeticidade dos modelos jurídicos processa-se sincrônica e diacronicamente com a da experiência social de que participam e da qual são momentos essenciais. 0 que disse, portanto, sobre o direito, quanto à sua gênese, pode-se repetir no concernente à sua validade, pois nenhuma norma jurídica vale como tal inseparável dos valores e dos fatos que compõem a estrutura ético-social de cada época e lugar. ${ }^{54}$

Os bens culturais, enquanto valores, são o que há de mais sagrado aos costumes, às crenças e à manutenção do povo, e, positivados em princípios constitucionais, conferem força normativa. Nesse sentido, quanto maiores forem a garantia de fundamentação legislativa em bens culturais coletivos e o grau de abertura democrática deliberativa inclusiva, mais força normativa terá a Constituição quanto à eficácia e à legitimidade. Especialmente pelo grau forte de legitimidade expresso na participação de todos os membros da comunidade. 0 intérprete observará na construção normativa a cultura como elemento integrador inclusivo e emancipador.

${ }^{54}$ REALE, Miguel. Horizontes do Direito e da História. 3. ed. São Paulo: Saraiva, 1999, p. 347. 
A Constituição se materializa enquanto processo dialético deliberativo inclusivo. A democracia é instrumento que assegura os meios e recursos para ser e fazer parte dela. Quanto maior o grau de deliberação participativa, maior a força normativa que confere efetividade à norma.

A ética (concepção aristotélica de equidade associada aos bens culturais disponíveis, valores e costumes, expressos nos princípios fundamentais como cultura que sedimenta a dignidade da pessoa humana) tem por objetivo a realização da justiça pelo reconhecimento do outro como sujeito de direito, sendo, dessa forma, inclusiva. Mas há uma dialogicidade nessa condução pelo intérprete, pelo partícipe, enquanto espaço democrático deliberativo legítimo, que conduz à efetividade pela força normativa da Constituição.

A ética dialógica do Direito tem por base os direitos fundamentais e sua irradiação para todo o sistema jurídico a partir do núcleo do ordenamento jurídico: o princípio da dignidade da pessoa humana. Nesse sentido, sintetizá-la como:

\title{
BENS CULTURAIS (CULTURA DE VALORES E PRINCÍPIOS) + DEMOCRACIA DELIBERATIVA- PARTICIPATIVA (LEGÍTIMA) = FORÇA NORMATIVA EFETIVA
}

A visão ética dialógica construída ao longo dos séculos no pluralismo de instâncias e atores sociais alarga o foco do Direito para além da lei. A existência de normas libertadoras se manifesta em princípios democráticos expressos na Constituição. Eis, portanto, que o Direito pode ser considerado como uma ciência social cuja legitimidade ultrapassa a simples legalidade, na qual deve prevalecer o “interesse público primário sobre o secundário”, como salienta Barroso. Supera-se a noção de sistema fechado, único e legitimado em si mesmo.

\begin{abstract}
A democracia em sentido material[...] que dá alma ao Estado constitucional de direito é, mais do que o governo da maioria, o governo para todos. Isso inclui não apenas as minorias -raciais, religiosas, culturais-, mas também os grupos de menor expressão política, ainda que não minoritários, como as mulheres e, em muitos países, os pobres em geral. [...] Impõe-se ao Estado, não apenas o respeito aos direitos individuais, mas igualmente a promoção de outros direitos fundamentais, de conteúdo social, necessários ao estabelecimento de patamares mínimos de igualdade material, sem a qual não existe vida digna nem é possível o desfrute da liberdade. ${ }^{56}$
\end{abstract}

55 “[...] o interesse público primário é a razão de ser do Estado e sintetiza-se nos fins que cabe a ele promover: justiça, segurança e bem-estar social. [...] o interesse público secundário [...] pode ser identificado como o interesse do erário, que é o de maximizar a arrecadação e minimizar as despesas". (BARROSO, Luís Roberto. Curso de Direito Constitucional Contemporâneo: os conceitos fundamentais e a construção do novo modelo. 4 ed. São Paulo: Saraiva, 2013, p. 92)

${ }^{56}$ Ibid., p. 63-64. 
Nesse sentido, vale ressaltar como valor-princípio a dignidade da pessoa humana como fundamento de todo ordenamento jurídico em consonância com princípios como a eticidade, a operabilidade e a sociabilidade.

\section{O ACESSO À JUSTIÇA}

Acerca das soluções práticas para os problemas de acesso à justiça, identifica-se que o Código de Processo Civil de 2015, Lei 13.105, visa a dar mais celeridade às demandas, inclusive com o uso de meios consensuais na solução de conflitos, como a conciliação, a mediação e a arbitragem, o negócio processual, o autorregramento da vontade, a cooperação processual, a razoável duração do processo, o contraditório, o devido processo legal, a razoabilidade e proporcionalidade, a boa-fé processual, a dignidade da pessoa humana e outros princípios que visam à realização do Direito justo na práxis jurídica, ou seja, próximo da eficácia social do processo com vistas ao acesso à justiça. $^{57}$ Nesse sentido identifica-se a relevância dos precedentes judiciais calcados em valores e princípios constitucionais como poderosos instrumentos de realização de um direito efetivo a partir do entendimento sedimentado pelos tribunais superiores, portanto fruto de processo democrático deliberativo participativo. Diametralmente oposta, encontra-se a percepção da norma como instrumento de criminalização, como regra processual e incentivo aos conflitos. A concepção ética do Direito aprimora a civilística-constitucional como norteadora do próprio direito público-privado, não focada numa estética patrimonialista, mas tendo como fonte valores e princípios como a boa-fé, a solidariedade, a dignidade da pessoa humana e outros fundamentos.

Trata-se, numa perspectiva ética dialógica do Direito, de uma aproximação entre o Direito público e o privado, baseada em valores e princípios civis-constitucionais. Assim, a concepção do Estado Democrático de Direito contempla dimensões dialógicas com vistas ao acesso à justiça. 0 CPC/2015 contempla, entre outras formas de cooperação e incentivo por meio de magistrados, advogados, partes, Ministério Público e defensores públicos, priorizando a busca pela solução de conflito pela conciliação e a mediação judicial (norteados pelos princípios da independência, da neutralidade, da autonomia da vontade, da confidencialidade, da oralidade e da informalidade), tanto no início como no curso do processo. E o intérprete, na busca do bem comum, observará os

${ }^{57}$ BRASIL. Lei ${ }^{\circ}$ 13.105, de 20 de abril de 2015. Dispõe sobre o Código de Processo Civil. In: Diário Oficial da República Federativa do Brasil, Brasília, DF, 16 mar. 2015. Disponível em: <http://www.planalto.gov.br/ccivil_03/_Ato2015-2018/2015/Lei/L13105.htm>. Acesso em: 04 jan. 2016. 
princípios da dignidade da pessoa humana, da razoabilidade, da legalidade, da impessoalidade, da moralidade, da publicidade e da eficiência. Destacam-se: a defensoria pública, na defesa dos hipossuficientes; o primoroso papel do auxiliar da justiça, com destaque para o amicus curiae, a partir da solicitação do juiz ou relator que considerar relevante a matéria, da especificidade do tema objeto da demanda, da repercussão social da lide ou do requerimento das partes ${ }^{58}$; e as audiências públicas, como instrumento democrático-participativo nos âmbitos administrativo e processual. A própria delação premiada, respeitados o contraditório e a ampla defesa (e não o cárcere como coerção), é poderoso instrumento democrático-participativo no processo.

O Direito, pensado numa perspectiva interpretativa principiológica, atenta para princípios norteadores da eticidade (boa-fé objetiva que conduza a um direito justo), sociabilidade (prevalência da coletividade sobre a individualidade preservando-se os direitos fundamentais previstos na Constituição Federal) e operabilidade (concretude e efetividade do direito) com vistas à solução pacificadora. Dessa forma, aproxima-se da comunidade pelo estímulo à participação social no processo.

A justiça social orienta todas as demais justiças (comutativa e distributiva) por carregar em si a virtude suprema, dizendo respeito à proteção da dignidade humana enquanto princípio universal que permeia o próprio Estado Democrático de Direito. Portanto, constitui-se essencialmente no campo da política jurídica pelo caráter de moralidade pública, por meio da correção das assimetrias sociais, com a aplicação dos princípios da igualdade, solidariedade e dignidade da pessoa humana, enquanto conquistas dos direitos humanos positivados na Constituição de 1988, e de sua efetivação, que assegure a todos existência digna e felicidade. A felicidade é aqui entendida objetivamente como justiça social e distributiva, ${ }^{59}$ expressa no conjunto de bens mínimos legalmente instituídos. Portanto, cabe ao Estado promover a conjugação do econômico com o social como objetivo fundamental, mediante a garantia de desenvolvimento nacional, a erradicação da pobreza, a redução de desigualdades sociais e

${ }^{58}$ Ibid.

59 "A Justiça Distributiva, por sua vez, consubstanciaria, para Aristóteles, a modalidade de Justiça que regularia, na esfera pública, as distribuições de bens e encargos promovidos pelos governantes aos cidadãos. Esta partilha teria como critério distributivo uma característica pessoal dos destinatários, que os diferenciaria dos demais sujeitos. [...] A função primordial do critério distributivo eleito seria a de mensurar a importância que o cidadão tinha para o todo social, comparativamente aos seus concorrentes. Definida esta relevância metonímica da parte para o todo, seria ela parâmetro de quantificação do quinhão devido ao sujeito, segundo uma igualdade proporcional que faria corresponder as relações existentes entre pessoas às relações entre os bens e ônus a ela devidos". (CASTILHO, R. dos S. Justiça Social e Distributiva: desafios para concretizar direitos sociais. São Paulo: Saraiva, 2009, p. 110-111) 
regionais, a construção de uma sociedade livre, justa e solidária que assegure existência digna a todos (art. $3^{\circ}$, I, II, III, IV da CRFB/1988), o que começa com educação de qualidade. ${ }^{60}$

Portanto, a justiça social diz respeito aos direitos e às garantias fundamentais do cidadão: capacidade de direitos civis, políticos e sociais - como participação política, liberdades de ir e vir, expressão, pensamento, igualdades -; em suma, o respeito à dignidade da pessoa humana.

[...] a existência digna de cada um só pode ser obtida pela Justiça Social (que determina a atribuição do mesmo conjunto de bens materiais e imateriais a todos, objeto dos direitos sociais de Justiça Social) e da Justiça Distributiva (que impõe a outorga de bens diversos a cada qual, segundo uma igualdade proporcional que leva em conta critérios pessoais, como o mérito e a necessidade, objeto dos direitos sociais de Justiça Distributiva). [...] a existência digna e plena de todo indivíduo - pressupõe que as pessoas a ele afetas também gozem da mesma situação. Pode-se supor que a vida digna de cada um pressuponha a existência minimamente satisfatória de todos os cidadãos, dado que situações de carência de qualquer pessoa podem pôr em risco todo o sistema de cooperação social. ${ }^{61}$

A essência do Direito é a liberdade e a da democracia é a igualdade material. Então, que seja dado a todos o direito de poder gozar dela e usufruí-la pela solidariedade. Esse é o grande dilema do nosso século: a inclusão do outro.

Ubiratan D’Ambrosio (2012), em Transdisciplinaridade, propõe a "ética da diversidade", que teria como princípios:

[...] 1. respeito pelo outro com todas as suas diferenças. 2. solidariedade com o outro na satisfação de necessidade de sobrevivência e de transcendência; 3 . Cooperação com o outro na preservação do patrimônio natural e cultural comum. $^{62}$

Essas considerações são essenciais no entendimento da concepção dialética cultural do Direito como movimento cíclico em que na diversidade se constrói um ambiente de convívio social elevado. Dentro do respeito, da cooperação e da solidariedade propostos por D’Ambrosio, pode-se afastar a pobreza como negação e exclusão, permitir a ruptura da pobreza com transformação e inclusão, e superar a pobreza com a emancipação.

Esses princípios colocam o conceito de 'identidade cultural' como essencial na construção de uma ideia de humanidade, pois as diversidades biológicas são, comparativamente às diversidades culturais, de menor complexidade. Portanto, surge como importante o exame da dinâmica cultural. Baseamos nossa

${ }^{60}$ Ibid., p. 98-117.

${ }^{61}$ CASTILHO, R. dos S. Justiça Social e Distributiva: desafios para concretizar direitos sociais. São Paulo: Saraiva, 2009, p. 96-97.

${ }^{62}$ D’AMBROSIO, U. Transdiciplinaridade. 3. ed. São Paulo: Palas Athena, 2012, p. 58. 
conceituação de dinâmica cultural em duas ideias fundamentais: A aquiescência, que é a capacidade de os indivíduos adquirirem mudanças conscientemente. $E$ o etos cultural, que age como um mecanismo de proteção contra as mudanças. A dinâmica cultural é o mecanismo comportamental que estabelece um balanço entre aquiescência e etos, permitindo a produção de novas formas culturais. A dinâmica cultural pode ser traçada às origens da civilização. ${ }^{63}$

Nesse sentido, a contribuição do movimento dialético, cíclico, é vista em relação ao movimento linear do poder belicista, inclusive nas relações autoritárias estabelecidas no cotidiano, entre o "mais forte" e o "mais fraco", ou entre incluídos e excluídos, como os pobres, desvalidos, ou mesmo qualquer sujeito não identificado com uma "estética cultural". Como expõe D’Ambrosio:

[...] sucesso social-político-militar do vencedor na identificação desse sucesso, por parte do vencido, como superioridade cultural do vencedor e nos fundamentalismos que dicotomizam as posições de vencedor e vencido. ${ }^{64}$

Incluir o outro é permitir o seu desenvolvimento em sua singularidade, na concepção kantiana do "homem como um fim em si-mesmo". Em grande medida, a pobreza humana se traduz em desrespeito, falta de solidariedade e de cooperação. Acrescenta-se também a banalização da violência de excluir por “prazer” ou para eliminar o concorrente. Por fim, entende D' Ambrosio que "as violações da paz" são violações éticas aos princípios do respeito, da solidariedade e da cooperação. Assim, o respeito levaria à paz interior; a solidariedade, à paz social; e a cooperação, à paz ambiental. ${ }^{65}$

Ainda, cabe citar a relevância da política como fomentadora de uma cultura cooperativa, dialógica e como instrumento capaz de dar sustentação ao arcabouço jurídico. Nesse sentido, referimo-nos a Amartya Sen (2010), que identifica na análise da preeminência das "liberdades políticas e da democracia" a primazia dos direitos políticos e civis básicos:

1) sua importância direta para a vida humana associada a capacidades básicas (como a capacidade de participação política e social); 2) seu papel instrumental de aumentar o grau em que as pessoas são ouvidas quando expressam e defendem suas reivindicações de atenção política (como as reivindicações de necessidades econômicas); 3) seu papel construtivo na conceituação de 'necessidades' (como a compreensão das 'necessidades econômicas' em um contexto social). ${ }^{66}$

${ }^{63}$ Ibid., p. 58.

${ }^{64}$ D’AMBROSIO, U. Transdiciplinaridade. 3. ed. São Paulo: Palas Athena, 2012, p. 58-59.

${ }^{65}$ Ibid., p. 155.

${ }^{66}$ SEN, A. Desenvolvimento como liberdade. São Paulo: Companhia das Letras, 2010, p. 195. 


\section{CONCLUSÃO}

No estudo da Ética Dialógica Culturalista do Direito, faz-se mister pensar a pluralidade de instâncias e de atores sociais a partir da democracia deliberativa-participativa, ou seja, de um plano abstrato ao concreto na efetividade do Direito. A concepção da Constituição como o conjunto de valores construídos ao longo dos mais de 514 anos de existência do Brasil, pelo povo, e não para o povo, traduz pouca efetividade normativa num direito ilegítimo. Vivenciamse relações de poder em geral patrimonialistas, "cordiais", clientelistas e ao mesmo tempo de desrespeito aos direitos fundamentais, que negam a democracia deliberativa participativa. Pois o Direito na práxis normativa está preso a valores e tradições díspares da realidade social (diversa e plural de instâncias sociais) e tem visado prioritariamente a manter o status quo. Revelam-se tais questões sociais, políticas, jurídicas e culturais na própria crise de legitimidade das instituições, pela carência de sintonia entre o que é o ser-social (suas contradições, desejos, necessidades) e o dever-ser (ciência do Direito). Os intérpretes, os legisladores e demais atores que lidam e operam com a norma têm agido a partir do subjetivismo (valores construídos a partir de seu mundo e de sua classe social), e não voltados ao que a população espera dos seus representantes constituídos: que a norma produza a eficácia social.

Traduz-se o Direito ilegítimo numa cultura excludente, que deixa de elevar o homem à condição de convivência digna. Nesse diapasão, faz-se mister pensar a Constituição culturalista no entendimento do Direito na Pós-Modernidade. A consideração dos valores histórico-culturais constitucionais interpretados com base nos axiomas e princípios permite corrigir assimetrias do passado e do presente.

O Direito não é produto de um pensamento unívoco, dominante, mas de relações éticas, jurídico-políticas, históricas, sociais, culturais e institucionais. Quanto mais participação social e aproximação da comunidade, maior a efetividade normativa. Nesse sentido, destacam-se meios judiciais e extrajudiciais como: os precedentes judiciais com vistas à pacificação social no processo; o amicus curiae; as audiências públicas; as soluções consensuais de conflitos (mediação, conciliação, arbitragem); a cooperação; a boa-fé processual; o autorregramento da vontade no processo; a primazia da solução de mérito; a proporcionalidade e razoabilidade; a administração dialógica. Os princípios e valores constitucionais são a base que assegura a eficácia social dos Direitos Fundamentais, com estrutura na dignidade da pessoa humana.

A formação da ética dialógica do Direito visa a contemplar a diversidade e o pluralismo para que se chegue à vida boa - uma sociedade melhor, com vida digna para todos. A cultura 
ética dialógica, axiológica e principiológica buscam a inclusão e a emancipação humanas, mediante os instrumentos deliberativo-participativos anteriormente especificados.

\section{REFERÊNCIAS}

ARISTÓTELES. Ética a Nicômaco. 4. ed. Brasília: Universidade de Brasília, 2001.

ARISTÓTELES. Política. 6. ed., São Paulo: Martin Claret, 2011.

ARENDT, H. Origens do Totalitarismo. São Paulo: Companhia das Letras. São Paulo, 2011.

BAUMAN, Z. Tempos Líquidos. Rio de Janeiro: Jorge Zahar Editor, 2007.

BARROSO, Luís Roberto. Curso de Direito Constitucional Contemporâneo: os conceitos fundamentais e a construção do novo modelo. 4 ed. São Paulo: Saraiva, 2013.

BERTEN, A. Modernidade e desencantamento: Nietzsche, Weber e Foucault. São Paulo: Saraiva, 2011.

BOBBIO, N. Liberalismo e Democracia. 6. ed., São Paulo, Brasiliense, 1994.

BRASIL. Constituição da República Federativa do Brasil de 1988. 9. ed. São Paulo: Revista dos Tribunais, 2004. 315 p.

BRASIL. Lei n 13.105, de 20 de abril de 2015. Dispõe sobre o Código de Processo Civil. Diário Oficial da República Federativa do Brasil, Brasília, DF, 16 mar. 2015. Disponível em: <http://www.planalto.gov.br/ccivil_03/_Ato2015-2018/2015/Lei/L13105.htm>. Acesso em: 04 jan. 2016.

CASTILHO, R. dos S. Justiça Social e Distributiva: desafios para concretizar direitos sociais. São Paulo: Saraiva, 2009.

CASTILHO, R. dos S. Refundação do Direito Econômico sob a égide dos Direitos Humanos: o Capitalismo Humanista. In: CAMPELLO, L. G. B.; SANTIAGO, M. R. (Coords.). Capitalismo Humanista e Direitos Humanos: Estudos em homenagem aos Professores Ricardo Sayeg e Wagner Balera. Florianópolis: Conceito Editorial, 2013.

CHAUI, Marilena. Acerca da moralidade pública. Folha de São Paulo. São Paulo, 24 maio 2001. Caderno Tendências/Debates.

CHAUI, Marilena. Convite à Filosofia. 13. ed. São Paulo: Ática, 2006.

COMPARATO, F. K. A afirmação histórica dos direitos humanos. 6. ed. São Paulo: Saraiva, 2008.

D’AMBRÓSIO, U. Transdiciplinaridade. 3. ed. São Paulo: Palas Athena, 2012. 
FERRAZ JR., T. S. Estudos de Filosofia do Direito: reflexões sobre o poder, a liberdade, a justiça e o direito. 2. ed. São Paulo: Atlas, 2003.

FREITAS, J. A Interpretação Sistemática do Direito. 5. ed. São Paulo: Malheiros, 2010.

HABERMAS, J. Direito e democracia: entre facticidade e validade. Rio de Janeiro: Tempo Brasileiro, 2011. v. 2.

HOLANDA, S. B. de. Raízes do Brasil. São Paulo: Companhia da Letras, 2008.

JACINTHO, J. M. M. Dignidade Humana: Princípio Constitucional. Curitiba: Editora Juruá, 2006.

KANT, I. Fundamentação da metafísica dos costumes e outros escritos: texto integral. São Paulo: Martin Claret, 2008.

MAAR, W. L. O que é política. Coleção Primeiros Passos. 16. ed. São Paulo: Brasiliense, 1994.

MAGALHÃES, T. C. de. A Reflexão de Ricoeur sobre o Justo. Síntese - Revista de Filosofia.

FAFICH/UFMG. Belo Horizonte, v. 29, n. 93, p. 103-115, 2002.

MILL, S. Considerações Sobre o Governo representativo. Coleção Grandes Obras do Pensamento Universal - 56. São Paulo: Editora Escala, 2006.

MONTESQUIEU. O Espírito das Leis. 1. ed. São Paulo: Martins Fontes, 1993.

MORAES, M. C. B. de. Perspectivas a partir do Direito Civil-Constitucional. In: TEPEDINO, G. (Org.). Direito civil contemporâneo: novos problemas à luz da legalidade constitucional. São Paulo: Editora Atlas, 2008.

MUNOZ, F. A. G. A justiça e a sabedoria prática em Paul Ricoeur. 2011. Dissertação (Mestrado) - Universidade São Judas Tadeu, São Paulo. 2011.

OLIVEIRA SOBRINHO, A. S. de. A Pobreza na cidade de São Paulo como negação aos Direitos Humanos Fundamentais: a ética dialógica do Direito. 2015. Tese (Doutorado em Direito) Faculdade Autônoma de Direito, FADISP, 2015.

REALE, M. Horizontes do Direito e da História. 3. ed. São Paulo: Saraiva, 1999.

RICOEUR, P. O Justo 1. A justiça como regra moral e como instituição. 1. ed. São Paulo: WMF Martins Fontes, 2008.

RICOEUR, P. Os Três Níveis do Juízo Médico. Colecção: Textos Clássicos LUSOSOFIA. Universidade da Beira Interior. Covilhã, 2010.

ROUSSEAU, J. O Contrato Social. 2. ed. Col. Grandes Obras do Pensamento Universal -13. São Paulo: Escala, 2008.

SANTOS, M. Por uma outra globalização: do pensamento único à consciência universal. 19. ed. Rio de Janeiro: Record, 2010. 
ISSN 1981-3694

(DOI): $10.5902 / 1981369422019$

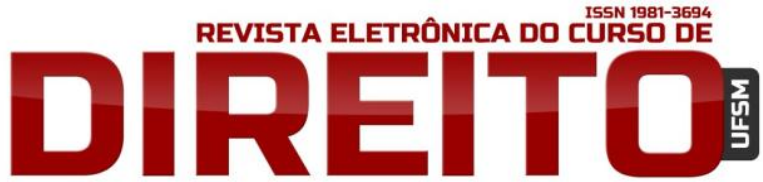

A ÉTICA DIALÓGICA CULTURALISTA DO DIREITO AFONSO SOARES OLIVEIRA SOBRINHO

SEN, A. Desenvolvimento como liberdade. São Paulo: Companhia das Letras, 2010.

TEIXEIRA, J. H. M.; GARCIA, M. (Orgs.). Curso de Direito Constitucional. Rio de Janeiro: Forense Universitária, 1991.

VALLS, Á. L. M. O que é ética. 9. ed. São Paulo: Brasiliense, 1994.

Recebido em: 06/05/2016 / Revisões requeridas em: 30/05/2016 / Aprovado em: 04/07/2016 